\title{
MR Contrast Agents from Viral Capsid Shells: A Comparison of Exterior and Interior Cargo Strategies
}

\author{
Jacob M. Hooker, ${ }^{1}$ Ankona Datta, ${ }^{1}$ Mauro Botta, ${ }^{2}$ Kenneth N. Raymond, ${ }^{1}$ and Matthew B. Francis, ${ }^{1,3, *}$
}

${ }^{1}$ Department of Chemistry, University of California, Berkeley, California 94720-1460; ${ }^{2}$ Dipartimento di Scienze dell' Ambiente e della Vita, Università del Piemonte Orientale "A. Avogadro", Via Bellini 25/G, Alessandria, Italy; ${ }^{3}$ Materials Sciences Division, Lawrence Berkeley National Lab, Berkeley, California 94720

\section{SUPPORTING INFORMATION}

\section{CONTENTS}

General Procedures and Materials

Instrumentation and Sample Analysis Preparations

Preparation of $m t M S 2$ capsids

Synthesis and Characterization of Protein Reactive Compounds $\mathbf{2}$ and $\mathbf{5}$

Synthesis and Characterization of Linker Molecule $\mathbf{8}$

Synthesis and Characterization of bis-HOPO-TAM Ligand 10

Bioconjugation Reactions, Purifications, and Analyses

Exterior functionalization with $\mathbf{2}$

Interior functionalization with $\mathbf{5}$

Oxime forming reactions with $\mathbf{1 0}$

Gd-chelation reactions and controls

Gadolinium Content Analysis by (a) ICP-AES and

(b) Mineralization Monitored by Relaxometry

Relaxivity Determination

References
Page S10

Page S16

Page S2

Page S2

Page S4

Page S4

Page S7

Page S8

Page S10

Page S11

Page S12

Page S15

Page S17 


\section{General Procedures and Materials}

Unless otherwise noted, all chemicals were of analytical grade obtained from commercial sources and used without further purification. Analytical thin layer chromatography (TLC) was performed on EM Reagent $0.25 \mathrm{~mm}$ silica gel $60-\mathrm{F}_{254}$ glass plates with visualization by ultraviolet (UV) irradiation at $254 \mathrm{~nm}$. Purifications by flash chromatography were performed using EM silica gel 60 (230-400 mesh). The eluting system for each purification was determined by TLC analysis. Chromatography solvents were used without distillation unless otherwise noted. Pyridine was distilled under a nitrogen atmosphere from calcium hydride. All reactions were carried out under an argon atmosphere unless otherwise noted. Water $\left(\mathrm{ddH}_{2} \mathrm{O}\right)$ used in biological procedures or as a reaction solvent was deionized using a NANOpure ${ }^{\mathrm{TM}}$ purification system (Barnstead, USA). All organic solvents were removed under reduced pressure using a rotary evaporator.

\section{Instrumentation and Sample Analysis Preparations}

UV-Vis spectroscopic measurements were conducted on a Tidas-II benchtop spectrophotometer (J \& M, Germany). Centrifugations were conducted with the following: 1) Allegra 64R Tabletop Centrifuge (Beckman Coulter, Inc., USA); 2) Sorvall RC5C refrigerated high-speed centrifuge (Sorvall, USA); or 3) Microfuge ${ }^{\circledR} 18$ centrifuge (Beckman Coulter, Inc., USA).

NMR. ${ }^{1} \mathrm{H}$ and ${ }^{13} \mathrm{C}$ spectra were measured with a Bruker AVQ-400 (400 MHz), Bruker DRX-500 (500 MHz) spectrometer, or a Bruker AVB-400 $(400 \mathrm{MHz})$ spectrometer as noted. Chemical shifts are reported as $\delta$ in units of parts per million (ppm) relative $\mathrm{CDCl}_{3}\left(\delta\right.$ 7.26, singlet), methanol- $d_{4}\left(\delta 3.31\right.$, pentet), dimethyl sulfoxide- $d_{6}$ ( $\delta 2.50$, pentet), or acetonitrile- $d_{3}(\delta 1.93$, pentet). Multiplicities are reported as follows: s (singlet), d (doublet), t (triplet), q (quartet), dd (doublet of doublets), m (multiplet), br (broadened), or app (apparent). Coupling constants are reported as a $J$ value in Hertz $(\mathrm{Hz})$. The number of protons $(\mathrm{n})$ for a given resonance is indicated $\mathrm{nH}$, and is based on spectral integration values. ${ }^{13} \mathrm{C}$ NMR chemical shifts are reported as $\delta$ in units of parts per million (ppm) relative to $\mathrm{CDCl}_{3}\left(\delta\right.$ 77.2, triplet), methanol- $d_{4}(\delta$ 49.0, septet), dimethyl sulfoxide- $d_{6}$ ( $\delta 39.5$, septet), or acetonitrile- $d_{3}(118.7$, singlet).

Mass Spectrometry (MS). Electrospray LC/MS analysis was performed using an API 150EX system (Applied Biosystems, USA) equipped with a Turbospray source and an Agilent 1100 series LC pump. Protein chromatography was performed using a Agilent ZORBAX ${ }^{\circledR} 300 \mathrm{SB}-\mathrm{C} 8$ reversed phase column $(2.1 \mathrm{~mm}$ x $50 \mathrm{~mm})$ with a $\mathrm{MeCN} \mathrm{ddH}_{2} \mathrm{O}$ gradient mobile phase containing $0.1 \%$ formic acid $(250 \mu \mathrm{L} / \mathrm{min})$ or with a Phenomenex Jupiter ${ }^{\mathrm{TM}} 3005 \mu \mathrm{C} 5300 \AA$ reversed-phase column ( $2.0 \mathrm{~mm} \times 150 \mathrm{~mm}$ ) with a $\mathrm{MeCN}: \mathrm{ddH}_{2} \mathrm{O}$ gradient mobile phase containing $0.1 \%$ formic acid ( $\left.250 \mu \mathrm{L} / \mathrm{min}\right)$. Protein mass reconstruction was performed on the charge ladder with Analyst software (version 1.3.1, Applied Biosystems). Matrix Assisted Laser Desorption-Ionization Time of Flight (MALDI-TOF) mass spectra were obtained on a Voyager-DE ${ }^{\mathrm{TM}}$ system (PerSeptive Biosystems, USA). Application of $0.5 \mu \mathrm{L}$ of a matrix solution containing 2,4,6-trihydroxyacetophenone (THAP) (38 mg/mL in 2:1 MeCN: $\mathrm{ddH}_{2} \mathrm{O}$ with $7 \mathrm{mg} / \mathrm{mL}$ ammonium chloride) was followed immediately by simultaneous application of $1 \mu \mathrm{L}$ of analyte solution in $\mathrm{ddH}_{2} \mathrm{O}$ and $0.5 \mu \mathrm{L}$ of glacial acetic acid. A repeat addition of another $0.5 \mu \mathrm{L}$ aliquot of the THAP matrix solution was followed by air drying for $0.5 \mathrm{~h}$ or until analysis. Routine MS analyses of synthetic organic molecules were carried out at the UC Berkeley Mass Spectrometry Facility and are noted by ionization technique: Fast Atom Bombardment (FAB) or Electron Impact (EI).

High Performance Liquid Chromatography. HPLC was performed on an Agilent 1100 Series HPLC System (Agilent 
Technologies, USA). Small molecule chromatography was achieved on C8 reversed-phase columns with a $\mathrm{MeCN}: \mathrm{H}_{2} \mathrm{O}$ gradient mobile phase containing $0.1 \%$ trifluoroacetic acid or $0.17 \mathrm{M}$ ammonium formate.

Analytical Size Exclusion Chromatography (SEC). Size exclusion chromatography was performed on an Agilent ZORBAX ${ }^{\circledR}$ GF-250 with isocratic (1.0 mL/min) flow using an aqueous mobile phase containing $100 \mathrm{mM} \mathrm{Na}_{2} \mathrm{HPO}_{4}$ (typically $\mathrm{pH}$ 7.2). Sample analysis for all HPLC experiments was achieved with an inline diode array detector (DAD) and an inline fluorescence detector (FLD).

Protein Purification. General desalting and removal of other small molecules of protein samples were achieved using $\operatorname{BioSpin}^{\circledR}$ G-25 centrifuge columns (Amersham Biosciences, USA) or NAP-5 ${ }^{\text {TM }}$ gel filtration columns (Amersham Biosciences, USA). Protein samples were concentrated by way of centrifugal ultrafiltration using Amicon ${ }^{\circledR}$ Ultra-4 or Ultra$15100 \mathrm{kDa}$ molecular weight cutoff spin columns (Millipore, USA). Dialysis was achieved with 10,000 molecular weight cutoff Slide-A-Lyzer® Dialysis Cassettes (Pierce Biotechnology, Inc., USA) as indicated below.

Gel Analyses. For protein analysis, sodium dodecyl sulfate-polyacrylamide gel electrophoresis (SDS-PAGE) was accomplished on a Mini-Protean apparatus (Bio-Rad, USA). Commercially available markers (Bio-Rad, USA) were applied to at least one lane of each gel for calculation of apparent molecular weights. Visualization of protein bands was accomplished by staining with Coomassie ${ }^{\circledR}$ Brilliant Blue R-250 (Bio-Rad, USA). Gel imaging was performed on an EpiChem3 Darkroom system (UVP, USA) and protein concentration was determined by densitometry and comparison to known standards.

Transmission Electron Microscopy (TEM) images were obtained at the UC-Berkeley Electron Microscope Lab using a FEI Tecnai 12 transmission electron microscope with $100 \mathrm{kV}$ accelerating voltage. Protein samples were prepared for TEM analysis by applying $5 \mu \mathrm{L}$ of an analyte solution at approximately $0.1 \mathrm{mg} / \mathrm{mL}$ to carbon-coated copper grids for 3 min followed by rinsing with $\mathrm{ddH}_{2} \mathrm{O}$. The grids were then exposed to $5 \mu \mathrm{L}$ of a $1 \%$ solution of uranyl acetate (UA) for 1.5 min as a negative stain. After excess stain was removed by blotting, the grid was allowed to dry until analysis.

Dynamic Light Scattering (DLS) data were obtained using a Zetasizer Nano Series (Malvern Instruments Limited, U.K.). For size and melting curve measurements, analyte solution at approximately $0.5 \mathrm{mg} / \mathrm{mL}$ in aqueous buffer was sterile filtered into glass cuvettes equipped with a Teflon cap. 


\section{Preparation of mtMS2 capsids}

MS2 and mtMS2. Routine propagation, purification, and characterization of the native bacteriophage MS2 (natMS2) followed by subsequent production of genome-free "empty" MS2 capsids (mtMS2) were accomplished using previously reported methods. ${ }^{1}$

\section{Synthesis and Characterization of Protein Reactive Compounds (2) and (5)}<smiles>O=Cc1ccc(C(=O)ON2C(=O)CCC2=O)cc1</smiles>

4-Formyl-benzoic acid 2,5-dioxo-pyrrolidin-1-yl ester (2). A stirred solution of $p$-formylbenzoic acid $(200 \mathrm{mg}, \quad 1.33 \mathrm{mmol}), \quad N$-hyrdroxysuccinimide $(230 \mathrm{mg}, 2.0 \mathrm{mmol})$, and $N, N$ diisopropylethylamine $(520 \mu \mathrm{L}, 3.0 \mathrm{mmol})$ in dry THF $(25 \mathrm{~mL})$ was cooled to $0{ }^{\circ} \mathrm{C}$ and treated in one portion with $N, N$-dicyclohxylcarbodiimide $(310 \mathrm{mg}, 1.5 \mathrm{mmol})$. The solution was stirred at $0{ }^{\circ} \mathrm{C}$ for $30 \mathrm{~min}$ and then allowed to warm to rt. Reaction progress was monitored by TLC (EtOAc). After $2 \mathrm{~h}$ at rt, the solution was concentrated under reduced pressure and then diluted with methylene chloride $(25 \mathrm{~mL})$. Insoluble material was removed by filtration and the solution was again concentrated under reduced pressure. The remaining mixture was again filtered and the eluent was applied to a silica-gel column. Flash chromatography (EtOAc:Hexanes) afforded $\mathbf{2}$ as a pure white solid (310 $\mathrm{mg}$, 94\% yield): ${ }^{1} \mathrm{H}$ NMR (500 MHz, $\left.\mathrm{CDCl}_{3}\right): \delta, 2.92$ (s, 4H), 8.01 (d, 2H, $\left.J=8.0 \mathrm{~Hz}\right), 8.28(\mathrm{~d}, 2 \mathrm{H}, J=8.0 \mathrm{~Hz}), 10.12(\mathrm{~s}, 1 \mathrm{H})$. ${ }^{13} \mathrm{C}$ NMR $\left(125 \mathrm{MHz}, \mathrm{CDCl}_{3}\right): \delta, 25.7,129.7,130.0,131.2,140.3,161.1,168.9,191.2$.

Scheme S1.
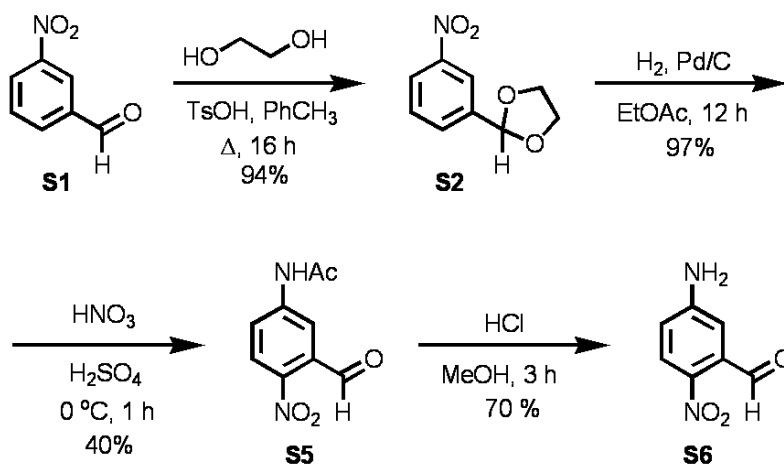

$\mathbf{5 5}$
$97 \%$
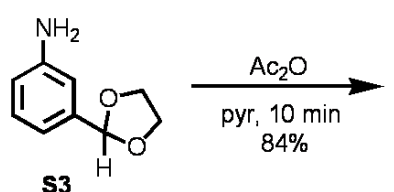<smiles>Nc1ccc([N+](=O)[O-])c(C=O)c1</smiles>

$\mathbf{5 6}$

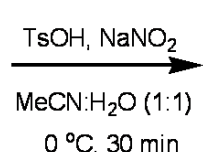

$0^{\circ} \mathrm{C}, 30 \mathrm{~min}$

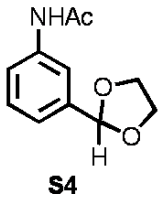

$\mathbf{S 4}$

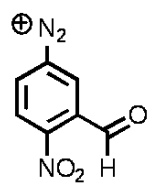

5

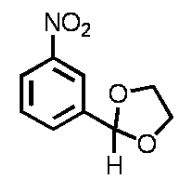

5-(Nitrophenyl)-1,3-dioxolane (S2). Protection of the aldehyde was performed by a modified procedure of several reports. ${ }^{2}$ 3-Nitrobenzaldehyde $(4.00 \mathrm{~g}, 26.4 \mathrm{mmol})$ was dissolved in toluene $(200 \mathrm{~mL})$ and treated sequentially with ethanediol $(3.0 \mathrm{~mL}, 53 \mathrm{mmol}, 2.0 \mathrm{eq})$ and $p$-TsOH $(150 \mathrm{mg}, 0.8 \mathrm{mmol})$. The resulting mixture was refluxed vigorously for $16 \mathrm{~h}$. After cooling to rt, mixture was washed with an aqueous solution of $5 \% \mathrm{NaHCO}_{3}$ $(2 \times 100 \mathrm{~mL})$ followed by brine $(1 \times 50 \mathrm{~mL})$. The organic layer was dried over $\mathrm{Na}_{2} \mathrm{SO}_{4}$ and concentrated under reduced pressure to afford a white solid $(4.9 \mathrm{~g}, 94 \%)$ that required no chromatographic purification. ${ }^{1} \mathrm{H}-\mathrm{NMR}\left(500 \mathrm{MHz}, \mathrm{CD}_{3} \mathrm{CN}, \delta\right)$ : $3.98-4.12(\mathrm{~m}, 4 \mathrm{H}), 5.85(\mathrm{~s}, 1 \mathrm{H}), 7.62(\mathrm{t}, 1 \mathrm{H}, J=8.0 \mathrm{~Hz}), 7.83(\mathrm{~d}, 1 \mathrm{H}, J=7.5 \mathrm{~Hz}), 8.21(\mathrm{dd}, 1 \mathrm{H}, J=1.2,8.0 \mathrm{~Hz}), 8.26(\mathrm{~d}, 1 \mathrm{H}$, 
$J=1.2 \mathrm{~Hz}) .{ }^{13} \mathrm{C}-\mathrm{NMR}\left(125 \mathrm{MHz}, \mathrm{CD}_{3} \mathrm{CN}\right), \delta: 65.3,101.9,121.2,123.9,129.7,132.9,140.7,148.3$. HRMS (FAB+) expected for $[\mathrm{M}+\mathrm{H}]^{+}, \mathrm{C}_{9} \mathrm{H}_{10} \mathrm{NO}_{4}{ }^{+}:$196.0610, found: 196.0614 .

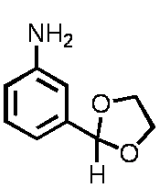

5-(Aminophenyl)-1,3-dioxolane (S3). To a solution of $\mathbf{S 2}(4.00 \mathrm{~g}, 20.5 \mathrm{mmol})$ in ethylacetate $(75 \mathrm{~mL})$ was added solid Pd/C (200 mg, $10 \mathrm{wt} \%$ ). The reaction atmosphere was exchanged several times with hydrogen gas $(\sim 2 \mathrm{~atm})$ and the reaction mixture was stirred rapidly at $\mathrm{rt}$ for $12 \mathrm{~h}$. The reaction mixture was poured through a plug of silica gel and the eluent was concentrated under reduced pressure affording $\mathbf{S 3}$ as a yellow-green oil (3.3 g, 97\%). The oil was found to polymerize over the course of several days and was best carried on to $\mathbf{S} 4$ for storage. Spectral characterization was in agreement with reported values. ${ }^{3}$ HRMS (FAB+) expected for $[\mathrm{M}+\mathrm{H}]^{+}, \mathrm{C}_{9} \mathrm{H}_{12} \mathrm{NO}_{2}{ }^{+}$: 166.0862, found: 166.0866.

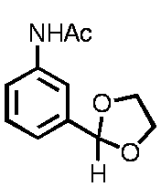

$N$-(3-1,3-Dioxolan-2-yl-phenyl)-acetamide (S4). To a solution of $\mathbf{S 3}(2.00 \mathrm{~g}, 12.1 \mathrm{mmol})$ in distilled pyridine $(25 \mathrm{~mL})$ was added $2 \mathrm{~mL}$ of acetic anhydride. The solution was stirred for $10 \mathrm{~min}$ at $\mathrm{rt}$ and then partitioned between $150 \mathrm{~mL}$ ethylacetate and $50 \mathrm{~mL}$ of an aqueous solution of $5 \% \mathrm{NaHCO}_{3}$. The organic layer was washed with $50 \mathrm{~mL}$ of water followed by $50 \mathrm{~mL}$ of brine, dried over $\mathrm{Na}_{2} \mathrm{SO}_{4}$, and finally concentrated under reduced pressure affording $\mathbf{S 4}(2.05 \mathrm{~g}, 84 \%)$ as a pure white solid. ${ }^{1} \mathrm{H}-\mathrm{NMR}\left(500 \mathrm{MHz}, \mathrm{CD}_{3} \mathrm{CN}, \delta\right): 2.08(\mathrm{~s}, 3 \mathrm{H}), 3.94-4.06$ $(\mathrm{m}, 4 \mathrm{H}), 5.70(\mathrm{~s}, 1 \mathrm{H}), 7.16(\mathrm{~d}, 1 \mathrm{H}, J=8.0 \mathrm{~Hz}), 7.32(\mathrm{t}, 1 \mathrm{H}, J=8.0 \mathrm{~Hz}), 7.55(\mathrm{~d}, 1 \mathrm{H}, J=8.0 \mathrm{~Hz}), 7.71(\mathrm{~s}, 1 \mathrm{H}), 8.61(\mathrm{~s}, 1 \mathrm{H})$. ${ }^{13} \mathrm{C}-\mathrm{NMR}\left(125 \mathrm{MHz}, \mathrm{CD}_{3} \mathrm{CN}\right), \delta: 23.4,65.1,103.1,117.4,120.0,121.7,128.7,139.09,139.14,168.9$. HRMS (FAB+) expected for $[\mathrm{M}+\mathrm{H}]^{+}, \mathrm{C}_{11} \mathrm{H}_{14} \mathrm{NO}_{3}{ }^{+}: 208.0974$, found: 208.0970 .

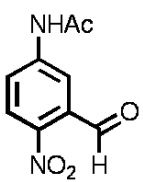

$N$-(3-(1,3-Dioxolan-2-yl)-4-nitrophenyl)-acetamide (S5). Nitration and aldehyde deprotection were carried out in one-pot as follows: To a cooled solution of conc. $\mathrm{H}_{2} \mathrm{SO}_{4}(15 \mathrm{~mL})$ was added a solid sample of $\mathbf{S 4}(1.0 \mathrm{~g}, 4.8$ mmol). The resulting solution was cooled to $0{ }^{\circ} \mathrm{C}$ with an external ice bath and then treated dropwise (over 30 min) with a solution of $90 \% \mathrm{HNO}_{3}(200 \mu \mathrm{L})$ in $\mathrm{H}_{2} \mathrm{SO}_{4}(4 \mathrm{~mL})$. After the addition of nitric acid was complete, the yellow reaction solution was stirred at $0{ }^{\circ} \mathrm{C}$ for an additional $30 \mathrm{~min}$. The solution was poured over crushed ice $(\sim 100$ $\mathrm{mL})$. After the ice had melted, the mixture was extracted with EtOAc $(100 \mathrm{~mL})$. All color transferred to the organic layer, which was then washed with an aqueous solution of $5 \% \mathrm{NaHCO}_{3}(25 \mathrm{~mL})$. The organic layer was dried over $\mathrm{Na}_{2} \mathrm{SO}_{4}$ and concentrated under reduced pressure to afford a yellow residue. Compound $\mathbf{S 5}$ was isolated as the major product by flash chromatography (EtOAc:Hexanes) affording $400 \mathrm{mg}(40 \%)$ as a yellow-white solid. ${ }^{1} \mathrm{H}-\mathrm{NMR}\left(500 \mathrm{MHz}, \mathrm{CD}_{3} \mathrm{CN}, \delta\right): 2.11$ $(\mathrm{s}, 3 \mathrm{H}), 7.91(\mathrm{dd}, 1 \mathrm{H}, J=2.5,9.0 \mathrm{~Hz}), 7.98(\mathrm{~d}, 1 \mathrm{H}, J=2.0 \mathrm{~Hz}), 8.09(\mathrm{~d}, 1 \mathrm{H}, J=9.0 \mathrm{~Hz}), 8.88(\mathrm{~s}, 1 \mathrm{H}), 10.31(\mathrm{~s}, 1 \mathrm{H}) .{ }^{13} \mathrm{C}-$ NMR (125 MHz, $\left.\mathrm{CD}_{3} \mathrm{CN}\right), \delta: 23.5,118.0,121.9,129.6,133.3,144.5,169.5,189.3$. HRMS (FAB+) expected for [M+H] ${ }^{+}$, $\mathrm{C}_{9} \mathrm{H}_{9} \mathrm{~N}_{2} \mathrm{O}_{4}^{+}: 209.0562$, found: 209.0564

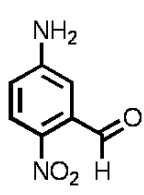

5-Amino-2-nitro-benzaldehyde (S6). A flask charged with a $25 \mathrm{~mL}$ solution of $\mathbf{S 5}$ (300 $\mathrm{mg}, 1.8 \mathrm{mmol}$ ) in $\mathrm{MeOH}$ was equipped with an $\mathrm{HCl}(\mathrm{g})$ line submerged in the reaction solution. The atmosphere was removed under vacuum and $\mathrm{HCl}(\mathrm{g})$ was introduced by bubbling through the reaction solution. $\mathrm{HCl}(\mathrm{g})$ was periodically added over the course of $2 \mathrm{~h}$. After an additional $1 \mathrm{~h}$ at $\mathrm{rt}$, the bright yellow solution was concentrated under 
reduced pressure. The yellow residue was dissolved in $50 \mathrm{~mL}$ EtOAc, which was washed with $5 \% \mathrm{NaHCO}_{3}$ (aq) and brine (25 mL each). The organic layer was dried over $\mathrm{Na}_{2} \mathrm{SO}_{4}$ and adsorbed onto silica gel under reduced pressure. Flash chromatography (EtOAc:Hexanes) afforded S6 $(210 \mathrm{mg}, 70 \%)$ as an orange solid. ${ }^{1} \mathrm{H}-\mathrm{NMR}\left(500 \mathrm{MHz}, \mathrm{DMSO}-d_{6} \delta\right): 6.73$ $(\mathrm{d}, 1 \mathrm{H}, J=2.5 \mathrm{~Hz}), 6.74(\mathrm{dd}, 1 \mathrm{H}, J=2.5,9.0 \mathrm{~Hz}), 6.99(\mathrm{~s}, 2 \mathrm{H}), 7.96(\mathrm{~d}, 1 \mathrm{H}, J=9.0 \mathrm{~Hz}), 10.26(\mathrm{~s}, 1 \mathrm{H}) .{ }^{13} \mathrm{C}-\mathrm{NMR}(125 \mathrm{MHz}$, DMSO- $d_{6}$ ), $\delta$ : 111.6, 114.8, 127.9, 135.5, 136.3, 155.2, 191.2. HRMS (EI+) expected for $[\mathrm{M}]^{+}, \mathrm{C}_{7} \mathrm{H}_{6} \mathrm{~N}_{2} \mathrm{O}_{3}{ }^{+}: 166.0378$, found: 166.0379 .

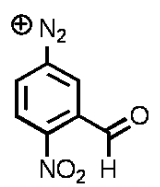

Diazonium salt (5). To $100 \mu \mathrm{L}$ of a $100 \mathrm{mM}$ solution of $\mathbf{S 6}$ in MeCN:DMF (1:1) was added $50 \mu \mathrm{L}$ of an aqueous solution of $p$-TsOH ( $800 \mathrm{mM}, 4$ equiv) in a $0.5 \mathrm{~mL}$ Eppendorf tube. The resulting solution was mixed by briefly vortexing and then cooled to $0{ }^{\circ} \mathrm{C}$ in an external ice bath. The cooled solution was treated with $5 \times 10$ $\mu \mathrm{L}$ aliquots of an aqueous solution of $\mathrm{NaNO}_{2}\left(400 \mathrm{mM}, 2\right.$ equiv) at $0{ }^{\circ} \mathrm{C}$. With each portion added, the solution was mixed thoroughly and incubated at $0{ }^{\circ} \mathrm{C}$ for $1 \mathrm{~min}$. Following the addition of the last aliquot of $\mathrm{NaNO}_{2}$, the diazotization reaction was allowed to proceed for $15 \mathrm{~min}$. This solution was used without further characterization or analysis for reaction with mtMS2 (see experimental details for $\mathbf{6}$ ). 


\section{Synthesis and Characterization of Linker Molecule (8)}

Scheme S2.

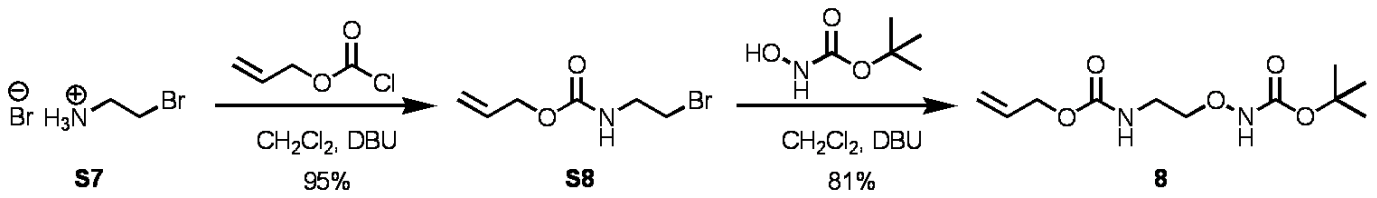

年 $\begin{aligned} & \mathrm{N} \text {-(Alloc)-2-bromoethylamine (S8). To a stirred mixture of 2-bromoethylamine hydrobromide (1.00 } \\ & \mathrm{g}, 4.88 \mathrm{mmol}) \text { in } \operatorname{dry} \mathrm{CH}_{2} \mathrm{Cl}_{2}(20 \mathrm{~mL}) \text { at } 0{ }^{\circ} \mathrm{C} \text { was added allylchloroformate }(614 \mathrm{mg}, 5.12 \mathrm{mmol}) \text { in }\end{aligned}$ one portion. The mixture was treated dropwise with DBU (3.7 g, $24.4 \mathrm{mmol})$ and the resulting solution was allowed to warm

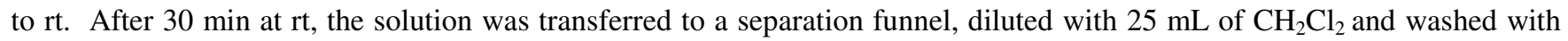
d.i. water $(2 \times 20 \mathrm{~mL})$. The organic layer was dried over $\mathrm{Na}_{2} \mathrm{SO}_{4}$ and then concentrated under reduced pressure. The resulting oil was purified by flash chromatography (EtOAc:Hexanes) affording S8 as a colorless oil (960 mg, 95\%). ${ }^{1} \mathrm{H}-\mathrm{NMR}$ $\left(500 \mathrm{MHz}, \mathrm{CD}_{3} \mathrm{Cl}, \delta\right): 3.25(\mathrm{t}, 2 \mathrm{H}, J=5.5 \mathrm{~Hz}), 3.37(\mathrm{t}, 2 \mathrm{H}, J=5.5 \mathrm{~Hz}), 4.36(\mathrm{~d}, 2 \mathrm{H}, J=5.5 \mathrm{~Hz}), 4.95(\mathrm{br}, 1 \mathrm{H}), 5.00(\mathrm{dd}$, $1 \mathrm{H}, J=1.0,10.5 \mathrm{~Hz}), 5.10(\mathrm{~m}, 1 \mathrm{H}, J=16.5), 5.66-5.74(\mathrm{~m}, 1 \mathrm{H}) .{ }^{13} \mathrm{C}-\mathrm{NMR}\left(125 \mathrm{MHz}, \mathrm{CD}_{3} \mathrm{Cl}\right), \delta: 32.5,40.5,42.7,117.9$, 132.6, 156.0. HRMS (FAB+) expected for $[\mathrm{M}+\mathrm{H}]^{+}\left(\mathrm{C}_{6} \mathrm{H}_{11} \mathrm{BrNO}_{2}\right): 207.9968$, found: 207.9964 .

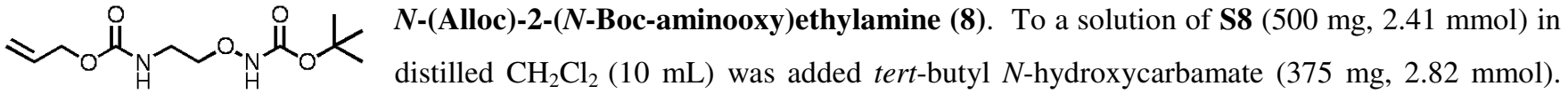
The resulting solution was treated dropwise with DBU (735 mg, $4.82 \mathrm{mmol})$. The reaction solution was heated to $30{ }^{\circ} \mathrm{C}$ and reaction progress was monitored by TLC (30\% EtOAc in Hexanes). After $48 \mathrm{~h}$ at $\mathrm{rt}$, the reaction solution was partitioned between $\mathrm{CH}_{2} \mathrm{Cl}_{2}(50 \mathrm{~mL})$ and water $(25 \mathrm{~mL})$. The organic layer was dried over $\mathrm{Na}_{2} \mathrm{SO}_{4}$ and concentrated under reduced pressure. Flash chromatography afforded $8(508 \mathrm{mg}, 81 \%)$ as a colorless oil. ${ }^{1} \mathrm{H}-\mathrm{NMR}\left(500 \mathrm{MHz}, \mathrm{CD}{ }_{3} \mathrm{Cl}, \delta\right): 1.46(\mathrm{~s}, 9 \mathrm{H})$, $3.40(\mathrm{dd}, 2 \mathrm{H}, J=4.5,5.5 \mathrm{~Hz}), 4.54(\mathrm{~d}, 2 \mathrm{H}, J=5.5 \mathrm{~Hz}), 5.17(\mathrm{dd}, 1 \mathrm{H}, J=1.0,10.0 \mathrm{~Hz}), 5.28(\mathrm{~m}, 1 \mathrm{H}, J=16 \mathrm{~Hz}), 5.72(\mathrm{br} \mathrm{s}$, 1H), 5.87-5.94 (m, 1H), 7.36 (br s, $1 \mathrm{H}) .{ }^{13} \mathrm{C}-\mathrm{NMR}\left(125 \mathrm{MHz}, \mathrm{CD}_{3} \mathrm{Cl}\right), \delta: 28.1,39.0,65.5,75.6,82.1,117.5,132.9,156.6$, 157.4. HRMS (FAB+) expected for $[\mathrm{M}+\mathrm{H}]^{+}\left(\mathrm{C}_{11} \mathrm{H}_{21} \mathrm{~N}_{2} \mathrm{O}_{5}\right): 261.1450$, found: 261.1444 


\section{Synthesis and Characterization of bis-HOPO-TAM Ligand (10)}

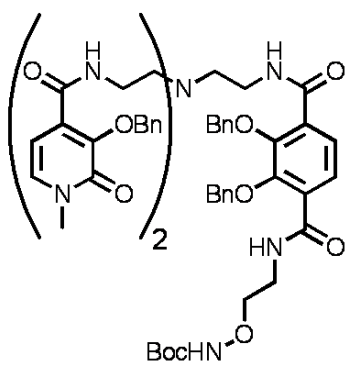

TREN-bis(HOPO-Bn)-TAM-Bn 2-Et-ONHBoc (9). AllocNHEtONHBoc (8) (50.0 mg, 0.192 mmol) was dissolved in $5 \mathrm{~mL}$ dichloromethane and treated with DABCO (107.0 mg, $0.96 \mathrm{mmol})$. To the resulting solution $\mathrm{Pd}\left(\mathrm{PPh}_{3}\right)_{4}(11.0 \mathrm{mg}, 9.6 . \mu \mathrm{mol})$ was added and stirred for $20 \mathrm{~min}$. TREN-bis(HOPO-Bn)-TAM-thiaz-Bn $\mathrm{Bn}_{2}$ (7) $(110.0 \mathrm{mg}, 0.101 \mathrm{mmol})$ was dissolved in $10 \mathrm{~mL}$ dichloromethane and added to the amine solution. The reaction mixture was stirred at room temperature for $48 \mathrm{hr}$ till the starting material was converted to the product as checked by TLC. The solvents were then evaporated under reduced pressure and the crude product was purified by flash chromatography eluting with a gradient of $100 \% \mathrm{CH}_{2} \mathrm{Cl}_{2}$ to $93 \% \mathrm{CH}_{2} \mathrm{Cl}_{2} / 7 \% \mathrm{CH}_{3} \mathrm{OH}$. The protected ligand was obtained as a pale yellow solid $\left.(81 \mathrm{mg}, 69.4 \%) .{ }^{1} \mathrm{H}-\mathrm{NMR}\left(300 \mathrm{MHz}, \mathrm{CDCl}_{3}\right): \delta=1.45(\mathrm{~s}, 9 \mathrm{H}, \mathrm{O}-\mathrm{C}(\mathrm{CH}))_{3}\right), 2.26(\mathrm{t}, 4 \mathrm{H}, \mathrm{N}-$ $\left.\mathrm{CH}_{2}-\mathrm{CH}_{2}-\mathrm{NH}-\mathrm{C}(\mathrm{O})-\mathrm{HOPO}, J=6\right), 2.34\left(\mathrm{t}, 2 \mathrm{H}, \mathrm{N}-\mathrm{CH}_{2}-\mathrm{CH}_{2}-\mathrm{NH}-\mathrm{C}(\mathrm{O})-\mathrm{TAM}, J=6\right), 3.10(\mathrm{q}, 4 \mathrm{H}, \mathrm{N}-\mathrm{CH}-\mathrm{CH}-\mathrm{NH}-\mathrm{C}(\mathrm{O})-$ HOPO, $J=6$ ), 3.17 (q, 2H, N-CH $-\mathrm{CH}_{2}-\mathrm{NH}-\mathrm{C}(\mathrm{O})-\mathrm{TAM}, \mathrm{J}=6$ ), 3.53 (s, 6H, ArN-CH $), 3.60$ (t, 2H, CH $-\mathrm{CH}$-O-NH-Boc, $J$ = 5), 3.84 (t, 2H, $\mathrm{CH}_{2}-\mathrm{CH}_{2}-\mathrm{O}-\mathrm{NH}-\mathrm{Boc}, \mathrm{J}=5$ ), 5.08 (s, 2H, O-CH2-Ar-TAM), 5.16 (s, 2H, O-CH $\left.-\mathrm{Ar}-\mathrm{TAM}\right), 5.28$ (s, 4H, O$\mathrm{CH}_{2}$-Ar-HOPO), 6.60 (d, 2H, HOPO-Ar- $\left.H, J=7\right), 7.07$ (d, 2H, HOPO-Ar- $H, J=7$ ), 7.37 - 7.24 (m, 20H, Ar- H), 7.60 (t, $1 \mathrm{H}$, $\mathrm{N}(H)-\mathrm{C}(\mathrm{O})$-TAM, $J=5), 7.65$ (d, 1H, TAM-Ar- $H, J=8), 7.75(\mathrm{~d}, 1 \mathrm{H}, \mathrm{TAM}-\mathrm{Ar}-H, J=8), 7.81(\mathrm{t}, 2 \mathrm{H}, \mathrm{N} H-\mathrm{C}(\mathrm{O})-\mathrm{HOPO}, J=$ 5), $8.22(\mathrm{t}, 1 \mathrm{H}, \mathrm{N} H-\mathrm{C}(\mathrm{O})-\mathrm{TAM}, J=5) .{ }^{13} \mathrm{C}-\mathrm{NMR}\left(300 \mathrm{MHz}, \mathrm{CDCl}_{3}\right) \quad \delta=28.4,37.4,37.9,38.1,52.2,52.5,74.85,75.0$, 81.9, 104.9, 125.9, 126.3, 128.7, 128.9, 129.1, 129.2, 130.6, 130.9, 131.9, 132.5, 136.4, 136.6, 146.6, 150.5, 150.7, 157.1, 159.8, 163.6, 165.0, 165.5. MALDI-MS (THAP) $\left[\mathrm{M}+\mathrm{H}^{+}\right] 1148.80$ (observed); 1148.28 (calculated for $\left[\mathrm{M}+\mathrm{H}^{+}\right]$).

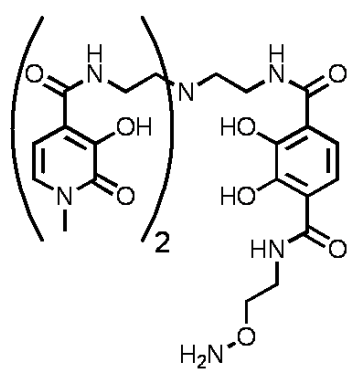

TREN-bis(HOPO)-TAM-Et-ONH 2 (10). TREN-bis(HOPO-Bn)-TAM-Bn 2 -Et-ONH- Boc (9) (81 mg, $0.071 \mathrm{mmol}$ ) was dissolved in $10 \mathrm{~mL}$ of a 1:1 mixture of concentrated $\mathrm{HCl}$ and glacial acetic acid. The reaction mixture was stirred under nitrogen at room temperature for $48 \mathrm{hr}$ until the starting material was completely deprotected, as checked by TLC. The solvents were evaporated under reduced pressure and traces of glacial acetic acid were removed by azeotroping with methanol several times. The product was dried under high vacuum overnight. The beige solid obtained was dissolved in minimum volume of methanol and added dropwise to $60 \mathrm{~mL}$ anhydrous diethyl ether. The product precipitated and was collected by filtration. The product obtained as a beige solid was characterized by ${ }^{1} \mathrm{H}-\mathrm{NMR}$ and used for bioconjugation studies with MS2 capsids. ${ }^{1} \mathrm{H}-\mathrm{NMR}\left(300 \mathrm{MHz}, \mathrm{CD}_{3} \mathrm{OD}\right) \delta=3.43$ (s, 6H, ArN-CH $), 3.60$ (b, 6H, N-CH $-\mathrm{CH}_{2}-\mathrm{NH}-\mathrm{C}(\mathrm{O})-\mathrm{HOPO}$ and N-CH$\left.-\mathrm{CH}_{2}-\mathrm{NH}-\mathrm{C}(\mathrm{O})-\mathrm{TAM}\right), 3.65\left(\mathrm{t}, 2 \mathrm{H}, \mathrm{CH}_{2}-\mathrm{CH}_{2}-\mathrm{O}-\mathrm{NH} \mathrm{H}_{2}, \mathrm{~J}\right.$ =5), 3.79 (b, 6H, N-CH2-CH $-\mathrm{NH}-\mathrm{C}(\mathrm{O})-\mathrm{HOPO}$ and $\left.\mathrm{N}_{2}-\mathrm{CH}_{2}-\mathrm{CH}_{2}-\mathrm{NH}-\mathrm{C}(\mathrm{O})-\mathrm{TAM}\right), 4.18\left(\mathrm{t}, 2 \mathrm{H}, \mathrm{CH}_{2}-\mathrm{CH}_{2}-\mathrm{O}-\mathrm{NH}_{2}, \mathrm{~J}=5\right), 6.25$ (d, 2H, HOPO-Ar-H, J = 7), 6.80 (d, 2H, HOPO-Ar-H, J = 7 ), 7.03 (d, 1H, TAM-Ar-H, J = 9 ), 7.06 (d, $1 \mathrm{H}, \mathrm{TAM}-\mathrm{Ar}-H, \mathrm{~J}=$ 9 ). ${ }^{13} \mathrm{C}-\mathrm{NMR}\left(500 \mathrm{MHz}, \mathrm{DMSO}-\mathrm{d}_{6}\right) \delta=33.9,34.0,36.9,37.3,48.6,51.5,72.4,102.7,116.1,116.3,116.7,117.2,127.6$, 147.6, 150.0, 158.0, 166.2, 168.9, 169.2 HPLC-MALDI-TOF MS m/z = $689\left(\mathrm{MH}^{+}\right)$, (Calcd. 687) CHN Analysis: Anal. Found for (10) $5 \mathrm{H}_{2} \mathrm{O} \cdot 2 \mathrm{HCl}$ (Calcd.). C 42.71 (42.41), H 5.82 (5.93), N 12.79 (13.19). 


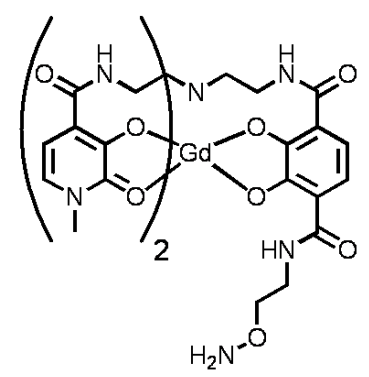

Gd-TREN-bis(HOPO)-TAM-Et-ONH 2 (15). TREN-bis(HOPO)-TAM-Et-ONH 2 (10) (2.53 mg, $0.003 \mathrm{mmol}$ ) was dissolved in $2 \mathrm{~mL}$ water and to it previously standardized aqueous $\mathrm{GdCl}_{3} \cdot 6 \mathrm{H}_{2} \mathrm{O}$ solution $(60 \mu \mathrm{L}$ of $45.2 \mathrm{mM}$ solution in $0.1 \mathrm{M} \mathrm{HCl})$ was added. The $\mathrm{pH}$ of the solution was adjusted to 7.4 by using $0.1 \mathrm{M} \mathrm{KOH}$ and $0.1 \mathrm{M} \mathrm{HCl}$. The solution was diluted to a final volume of $3.0 \mathrm{~mL}$ and filtered before measuring the $\mathrm{Gd}$ content. 


\section{$\underline{\text { Bioconjugation Reactions, Purifications, and Analyses }}$}

\section{Exterior functionalization with 2}

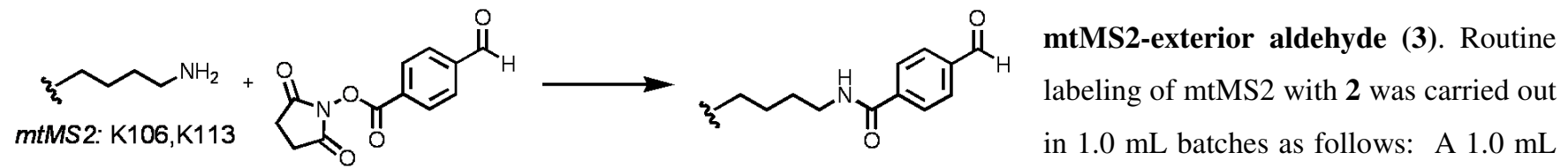

buffered solution of mtMS2 (250 $\mu \mathrm{M}$ in 'monomer', $\left.100 \mathrm{mM} \mathrm{NaH}_{2} \mathrm{PO}_{4}, \mathrm{pH} 9.0\right)$ was treated with $50 \mu \mathrm{L}$ of a solution of 2 (20 $\mathrm{mM}$ in DMF, 4 equiv). The resulting solution was incubated at $\mathrm{rt}$ on a rotating shaker for $2 \mathrm{~h}$. The mtMS2 conjugate was purified from unreacted small-molecule impurities using size-exclusion chromatography (NAP-10, $100 \mathrm{mM} \mathrm{NaH}_{2} \mathrm{PO}_{4}, \mathrm{pH}$ 7.2 eluent) followed by dialysis in a $0.5-3.0 \mathrm{~mL}$ Slide-A-Lyzer® Dialysis Cassette (10,000 MWCO) against $3 \mathrm{~L}$ of an aqueous buffer (10 $\mathrm{mM} \mathrm{NaH}_{2} \mathrm{PO}_{4}, \mathrm{pH}$ 6.5). Labeling efficiency was determined by ESI-MS (Figure $\mathrm{S} 1$ ) and capsid integrity was verified by analytical SEC (data not shown). The procedure provided mtMS2 conjugate 3 in $>95 \%$ protein recovery as determined by SDS-PAGE analysis. Purified samples were stored at $\mathrm{rt}$ and combined and concentrated as needed for subsequent reactions.

\section{Interior functionalization with $\mathbf{5}$}
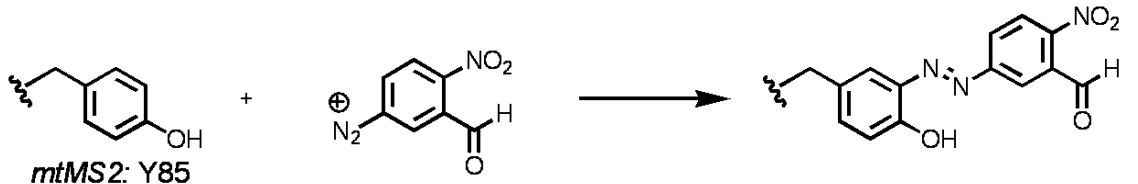

mtMS2-interior aldehyde (6). Routine labeling of mtMS2 with 5 was carried out in $1.0 \mathrm{~mL}$ batches as follows: To a 1.0 $\mathrm{mL}$ aqueous buffered solution of mtMS2 $\left(150 \mu \mathrm{M}\right.$ inY85, $\left.\mathrm{pH} 8.6,100 \mathrm{mM} \mathrm{NaH}_{2} \mathrm{PO}_{4}\right)$ at $4{ }^{\circ} \mathrm{C}$ was added $30 \mu \mathrm{L}$ of $5(\sim 10$ equiv). After briefly vortexing, the resulting orange solution was held at $4{ }^{\circ} \mathrm{C}$ for $30 \mathrm{~min}$. Two preparative size-exclusion chromatography purifications were carried out to remove small-molecule impurities (NAP-10, $100 \mathrm{mM} \mathrm{NaH}_{2} \mathrm{PO}_{4}, \mathrm{pH} 7.2$ eluent) followed by dialysis in a 0.5-3.0 mL Slide-A-Lyzer® Dialysis Cassette (10,000 MWCO) against $3 \mathrm{~L}$ of an aqueous buffer (10 mM NaH${ }_{2} \mathrm{PO}_{4}, \mathrm{pH}$ 6.5). Labeling efficiency was determined by ESI-MS (Figure S1) and verified by UV-Vis analysis of the azo conjugate (Figure S2). Capsid integrity was verified by analytical SEC (Figure S2). The procedure provided mtMS2 conjugate 3 with $\sim 90 \%$ protein recovery as determined by SDS-PAGE analysis. Purified samples were stored at $\mathrm{rt}$ and combined and concentrated as needed for subsequent reactions. 

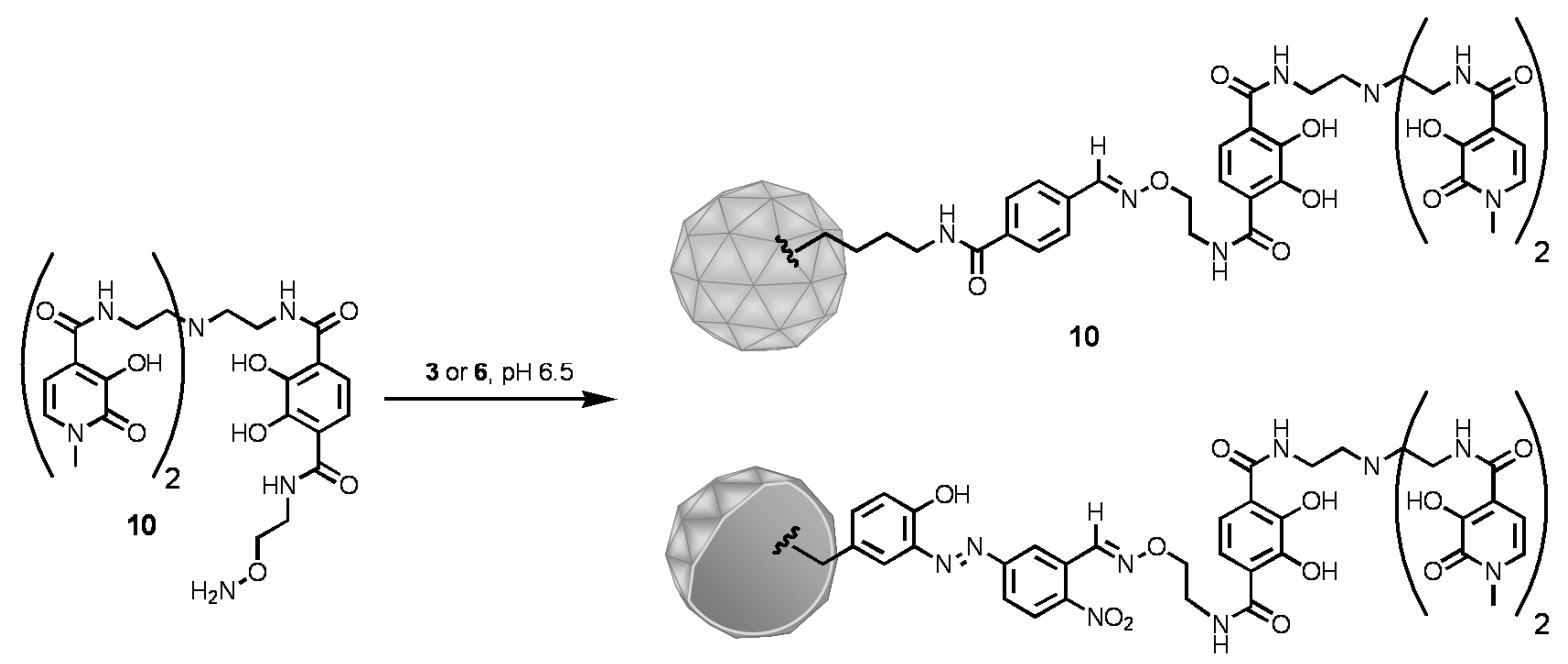

11

To a $10.0 \mathrm{~mL}$ solution of each 3 and $\mathbf{6}\left(\sim 1.0 \mathrm{mg} / \mathrm{mL}\right.$, in aqueous buffer $\left.100 \mathrm{mM} \mathrm{NaH}_{2} \mathrm{PO}_{4}, \mathrm{pH} 6.5\right)$ in a $15.0 \mathrm{~mL}$ Falcon tube was added $0.25 \mathrm{~mL}$ of an aqueous solution of $10(30 \mathrm{mM}, \sim 1.2$ equiv of ligand relative to aldehyde) in $50 \mu \mathrm{L}$ portions every hour. Each solution was continually agitated on a rotating shaker. After $8 \mathrm{~h}$ of agitation at $\mathrm{rt}$, the samples were centrifuged to remove insoluble material. The supernatant of each sample was transferred to a 3.0-12.0 mL Slide-A-Lyzer® Dialysis Cassette (10,000 MWCO) and each dialyzed against 3.0 L of aqueous buffer $\left(10 \mathrm{mM} \mathrm{NaH}_{2} \mathrm{PO}_{4}, \mathrm{pH} 6.5\right)$ at $\mathrm{rt}$ for $8 \mathrm{~h}$. The dialysis cassettes were each transferred to $3.0 \mathrm{~L}$ of $10 \mathrm{mM} \mathrm{NaOAc}, \mathrm{pH} 4.5$ for purification overnight. Finally, each sample was concentrated to $\sim 3 \mathrm{~mL}$ by Amicon ${ }^{\circledR}$ Ultra-15 (100,000 MWCO) centrifugation. Oxime formation was quantitative as determined by ESI-MS (Figure S1). Capsid integrity was verified by analytical SEC (Figure S2). The procedure provided mtMS2 conjugate 11 with $\sim 70 \%$ protein recovery and mtMS2 conjugate $\mathbf{1 2}$ with $\sim 90 \%$ protein recovery as determined by SDS-PAGE analysis. 

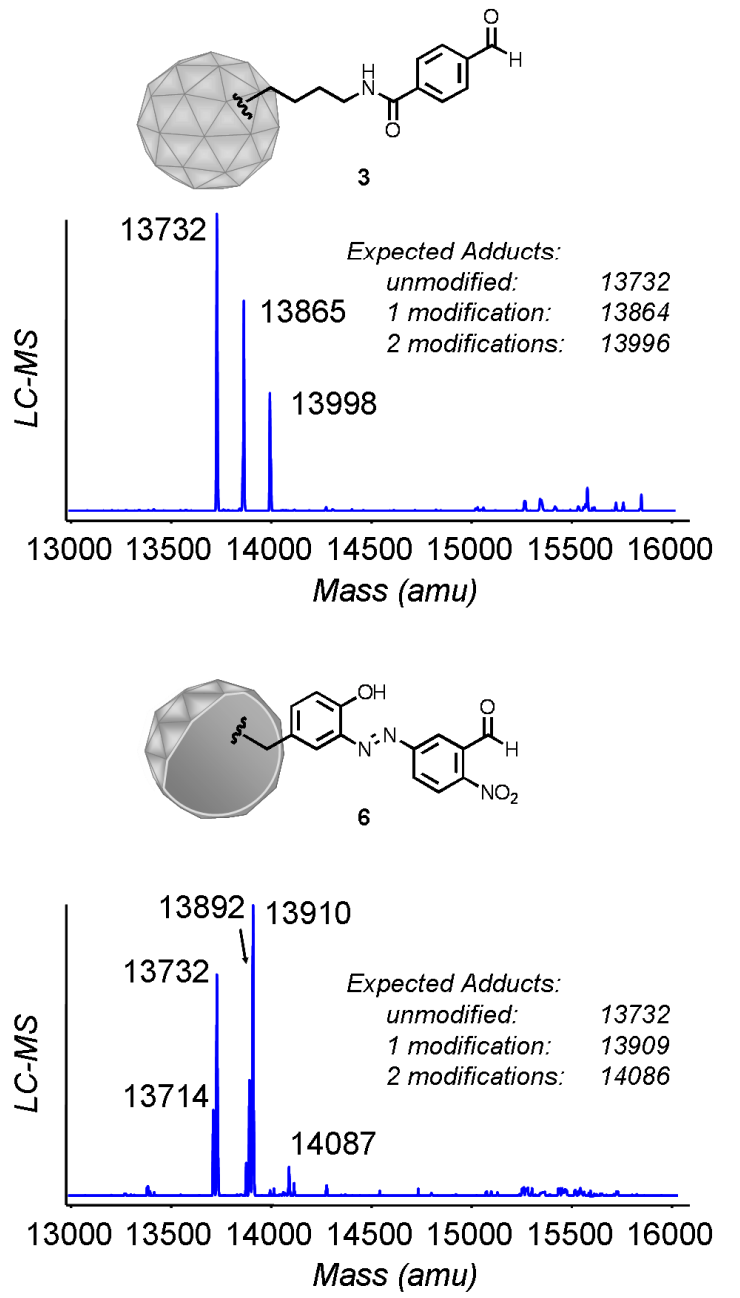
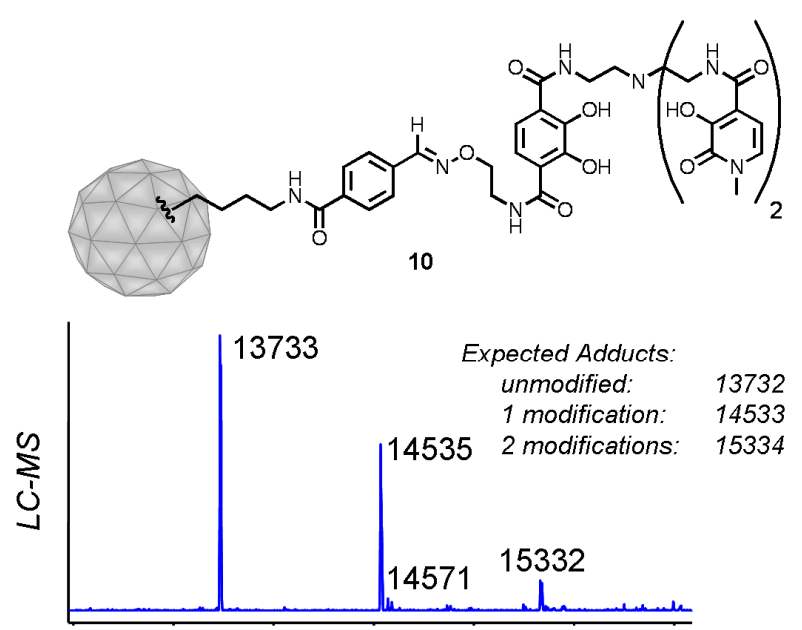

13000135001400014500150001550016000 Mass (amu)

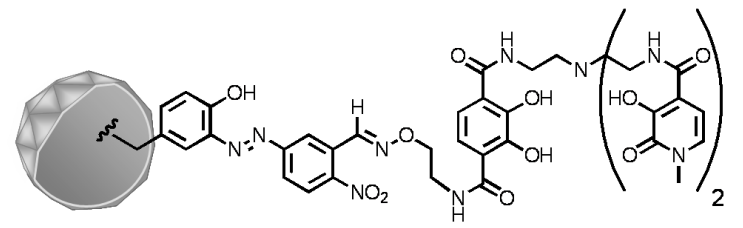

11

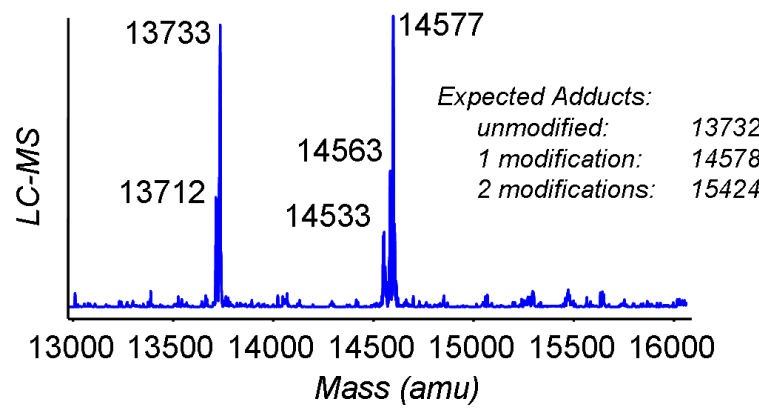

Figure S1. Mass spectral analysis of bioconjugates 3, 6, 10, and 11. Electrospray LC/MS analysis was performed using an API 150EX system (Applied Biosystems, USA) equipped with a Turbospray source and an Agilent 1100 series LC pump. Protein chromatography was performed using a Agilent ZORBAX ${ }^{\circledR} 300$ SB-C8 reversed phase column $(2.1 \mathrm{~mm} \times 50 \mathrm{~mm})$ with a $\mathrm{MeCN}: \mathrm{ddH}_{2} \mathrm{O}$ gradient mobile phase containing $0.1 \%$ formic acid $(250 \mu \mathrm{L} / \mathrm{min})$ or with a Phenomenex Jupiter 300 $5 \mu \mathrm{C} 5300 \AA$ reversed-phase column $(2.0 \mathrm{~mm} \times 150 \mathrm{~mm})$ with a $\mathrm{MeCN}: \mathrm{ddH}_{2} \mathrm{O}$ gradient mobile phase containing $0.1 \%$ formic acid $(250 \mu \mathrm{L} / \mathrm{min})$. Protein mass reconstruction was performed on the charge ladder with Analyst software (version 1.3.1, Applied Biosystems). 


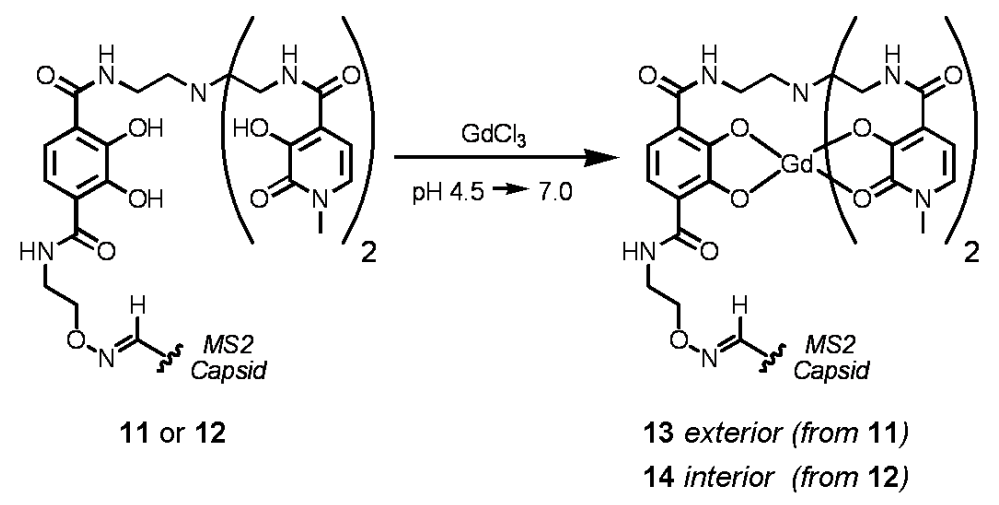

To each of the mtMS2-conjugates, 11 and 12, ( 2 $\mathrm{mg} / \mathrm{mL}, 2.0 \mathrm{~mL}, 10 \mathrm{mM} \mathrm{NaOAc}, \mathrm{pH} 4.5)$ was added a previously standardized aqueous $\mathrm{GdCl}_{3} \cdot 6 \mathrm{H}_{2} \mathrm{O}$ solution $(10.0 \mu \mathrm{L}$ of $45.2 \mathrm{mM}$ solution in $0.1 \mathrm{M} \mathrm{HCl})$ was added in $2.0 \mu \mathrm{L}$ portions. The resulting solutions were allowed to stand at $\mathrm{rt}$ for $\sim 15 \mathrm{~min}$. The $\mathrm{pH}$ was then adjusted neutral to $\mathrm{pH}$ paper by the slow addition of HEPES buffer (100 mM, pH 7.5). Each solution was purified using NAP-10 size exclusion columns (25 mM HEPES, pH 6.85) and then dialyzed against 3.0 L of buffer ( $25 \mathrm{mM}$ HEPES, pH 6.85) containing ammonium citrate $(0.5 \mathrm{mM})$ for $4 \mathrm{~h}$ at rt. Following an overnight dialysis against a fresh buffer (12.5 mM HEPES, $\mathrm{pH} 6.85)$, samples were concentrated Amicon ${ }^{\circledR}$ Ultra-4 (100,000 MWCO) centrifugation.

\section{a: Exterior MS2 Bioconjugate Analyses}

Analytical Size-Exclusion Chromatography

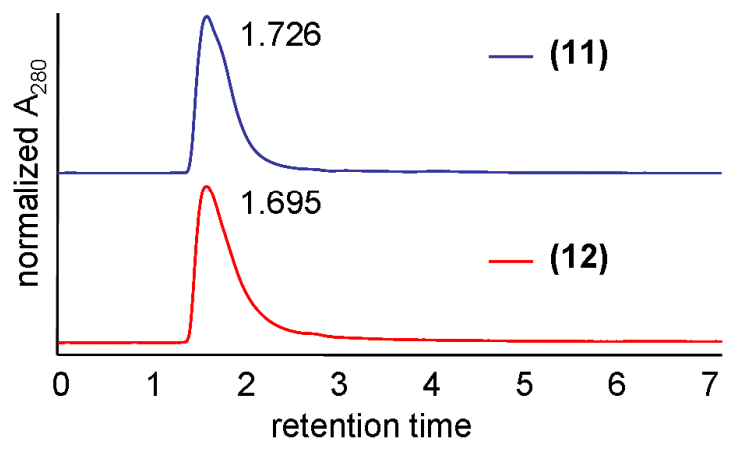

b: Interior MS2 Bioconjugate Analyses

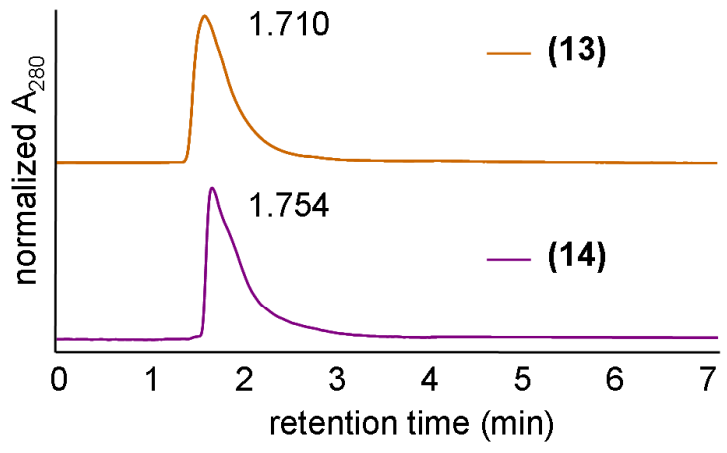

Diode Array UV-Vis Spectra
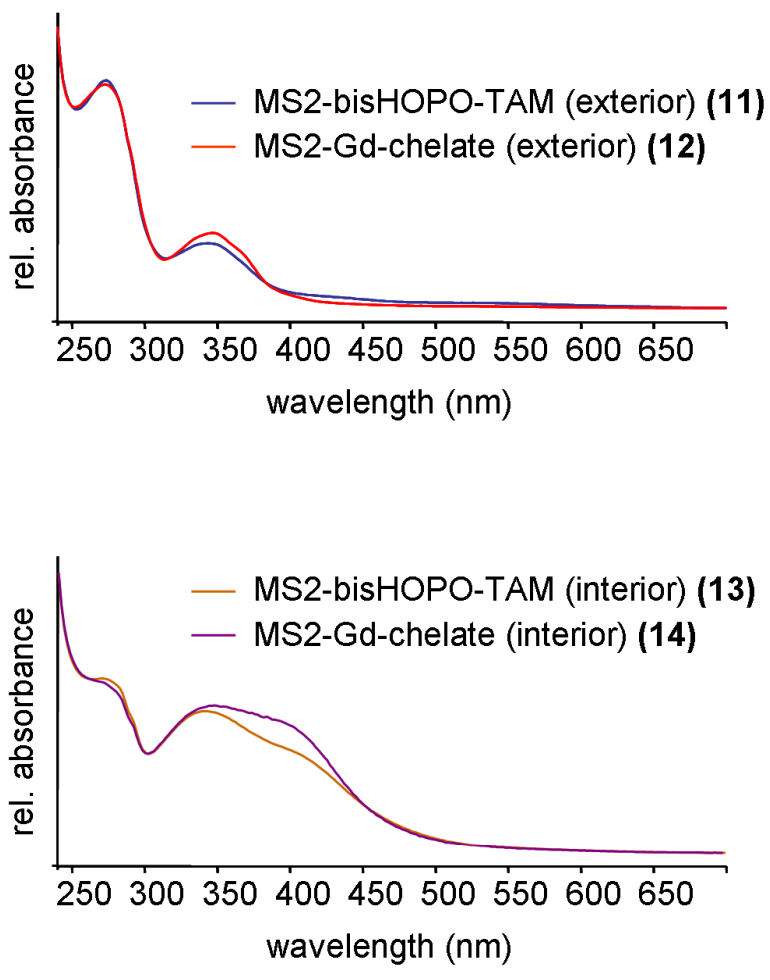

Figure S2. Size exclusion chromatography was performed on an Agilent ZORBAX ${ }^{\mathbb{B}}$ GF-250 with isocratic $(1.0 \mathrm{~mL} / \mathrm{min})$ flow using an aqueous mobile phase containing $100 \mathrm{mM} \mathrm{Na}_{2} \mathrm{HPO}_{4}(\mathrm{pH}$ 7.2). Intact MS2 capsid samples are not retained and elute at $\sim 1.7 \mathrm{~min}$ whereas monomeric protein species are expected at $\sim 3.5 \mathrm{~min}$. UV-Vis spectra were collected with an inline diode array detector (DAD). 

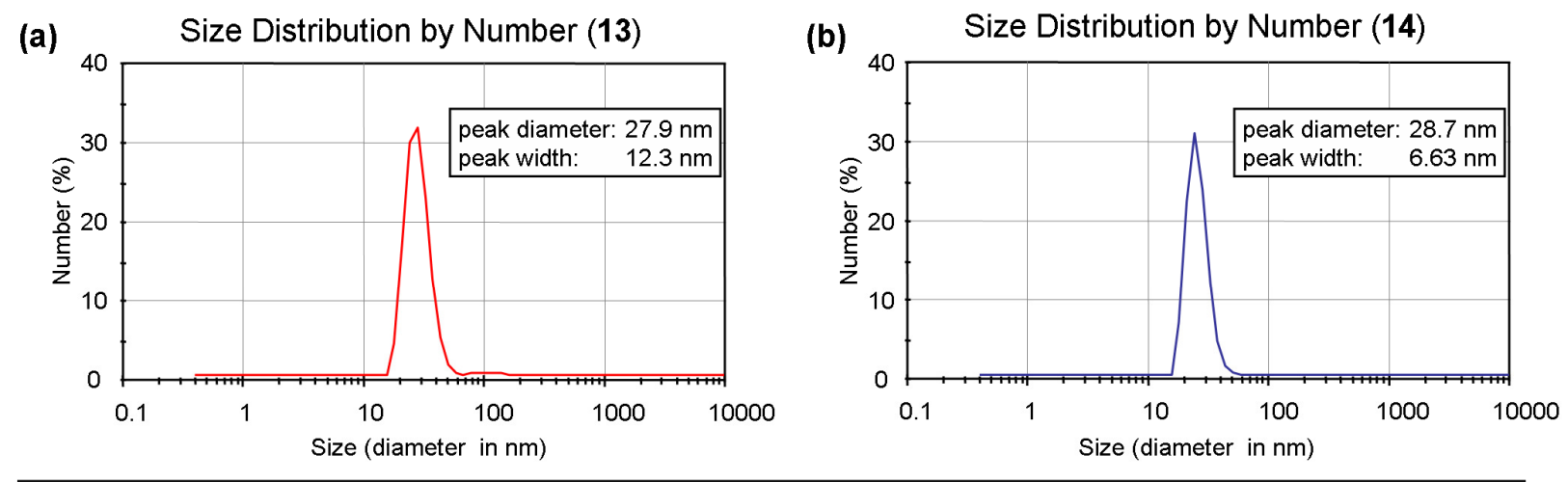

(c)

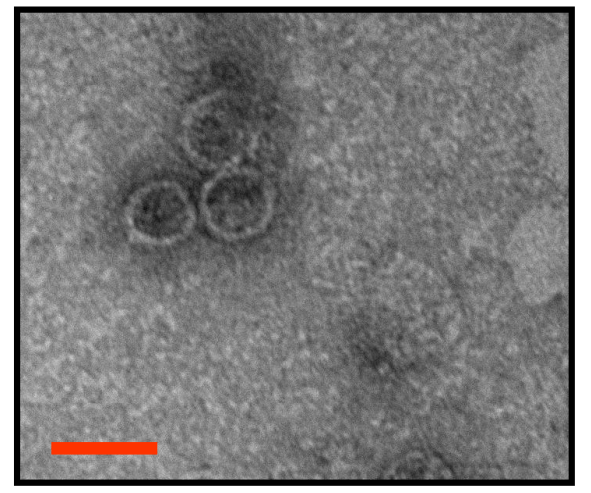

TEM image of 13

(d)

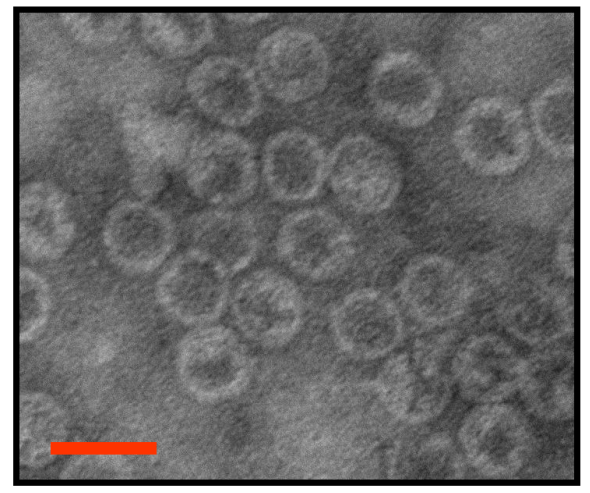

TEM image of 14

Figure S3. Structural characterization of MS2-based MR contrast agents. (a-b) Dynamic light scattering (DLS) measurements indicated that the particles were highly uniform and of the expected diameter $(22 \mathrm{~nm})$. (c-d) Transmission electron microscopy was used to verify the aggregate state. Samples were negatively stained with $1 \%$ solution of uranyl acetate. $($ Scale bar $=50 \mathrm{~nm})$

\section{Control experiments to test ligand-specific Gd-chelation}

Oxime condensation reactions with $O$-benzylhydroxylamine were accomplished using an analogous procedure detailed for compound 10. The resulting conjugates, $\mathbf{S 9}$ and $\mathbf{S 1 0}$, were incubated with $\mathrm{GdCl}_{3}$ and carried through the purification steps listed for 13 and 14. In addition, a sample of $225 \mu \mathrm{M} \mathrm{GdCl}_{3}$ was subjected to the purification sequence. Gd-content analysis by ICP-AES indicated minimal non-specific Gd incorporation (see Table S1). 

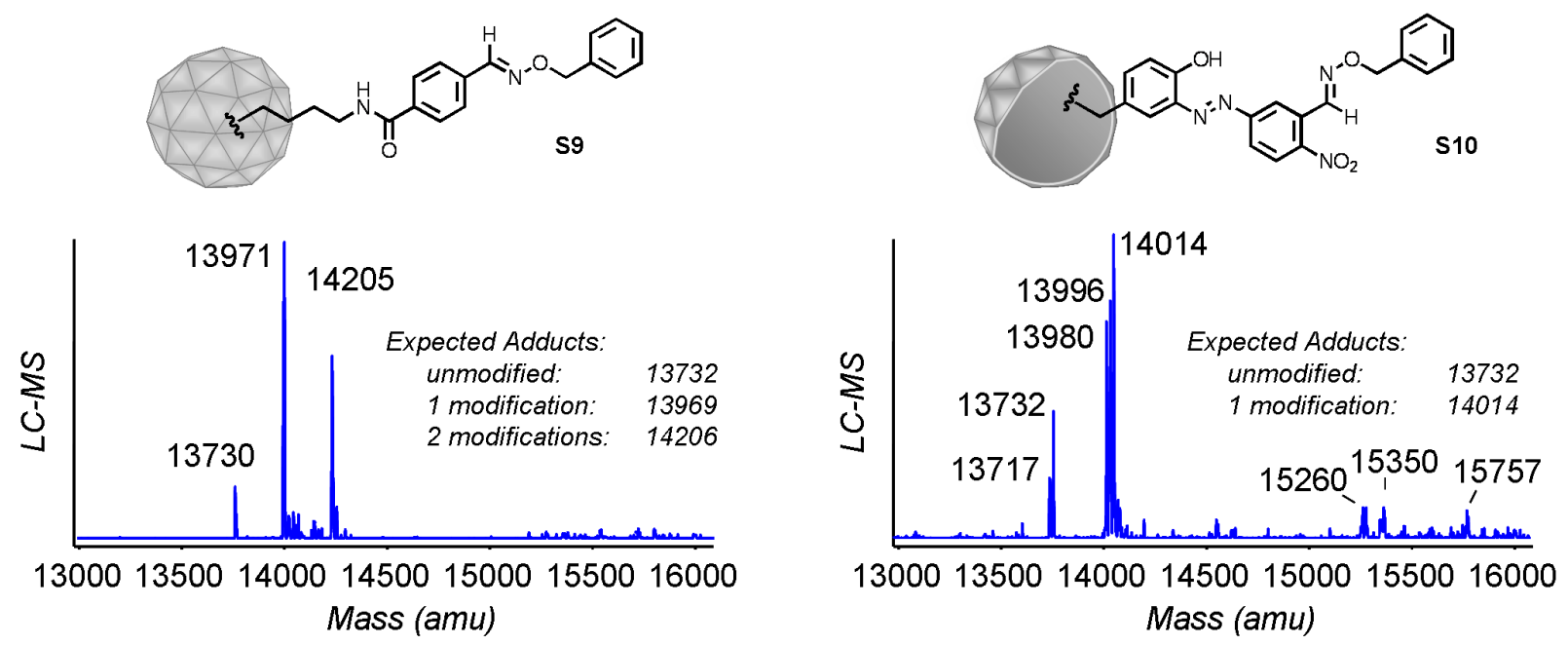

Figure S4. Mass spectral analysis of bioconjugates S9 and S10. Oxime conjugates with $O$-benzylhydroxylamine were synthesized. These samples were used as controls to demonstrate ligand specific Gd incorporation.

\section{Gadolinium Content Analysis by (a) ICP-AES and (b) Mineralization Monitored by Relaxometry}

(a) ICP-AES was accomplished on a Perkin-Elmer Optima 3000DV instrument. Standard Gd(III) solutions (100 - 1000 $\mathrm{ppb}, 10 \mathrm{~mL}$ each) in water were prepared from a previously standardized aqueous $\mathrm{GdCl}_{3} \cdot 6 \mathrm{H}_{2} \mathrm{O}$ solution $(45.2 \mathrm{mM}$ in $0.1 \mathrm{M}$ $\mathrm{HCl}$ ). The Gadolinium-content of these solutions was measured by ICP-AES. The gadolinium wavelengths monitored were 342.2, 336.2, 335.0, and $308.2 \mathrm{~nm}$. Calibration curves at each wavelength were generated from these measurements. The complex solutions and the complex-conjugated MS2 solutions were diluted with water so that their concentrations would range between 100-1000 $\mathrm{ppb}$ and then the intensity at each wavelength was measured and compared to the linear calibration data.

(b) Mineralization Monitored by Relaxometry ${ }^{4}$ : The gadolinium concentration of the complex-conjugated MS2 solutions was measured by a relaxometric procedure $\left(20 \mathrm{MHz}\right.$ and $\left.25^{\circ} \mathrm{C}\right)$. Three accurate determinations of the ${ }^{1} \mathrm{H}$ longitudinal water proton relaxation rate $\left(\mathrm{R}_{1}{ }^{\text {obs }}\right)$ were made at $\mathrm{pH}=6.9$ on ca. $0.2-0.5 \mathrm{mM}$ aqueous solutions. A volume of $100 \mu \mathrm{L}$ of each solutions was then added to $100 \mu \mathrm{L}$ of $\mathrm{HNO}_{3} 70 \%$ directly into a $1.0 \mathrm{~mL}$ glass ampule. After gentle centrifugation of the resulting solutions $(1500 \mathrm{rpm}, 2 \mathrm{~min})$ the ampules were sealed and heated at $120^{\circ} \mathrm{C}$ for 5 days. This treatment ensures that all $\mathrm{Gd}(\mathrm{III})$ is solubilized as the free aqua ion $\left[\mathrm{Gd}\left(\mathrm{H}_{2} \mathrm{O}\right)_{8}\right]^{3+}$. The $\mathrm{R}_{1}$ values $\left(\mathrm{R}_{1}{ }^{*}\right)$ were then measured again (three times) and the concentration of $\mathrm{Gd}(\mathrm{III})$ in the starting solutions calculated using the following expression: 


$$
\left.[\mathrm{Gd}]=\left[\left(\mathrm{R}_{1}^{*}-0.51\right) / 13.99\right] \times 2 \quad \text { (eq. } 1\right)
$$

where 13.99 is the relaxivity $\left(\mathrm{mM}^{-1} \mathrm{~s}^{-1}\right)$ of the aqua ion under identical experimental conditions and $0.51\left(\mathrm{~s}^{-1}\right)$ the relaxation rate of the diamagnetic solution $\left(1: 1\right.$ water and $\left.\mathrm{HNO}_{3} 70 \%\right)$.

Table S1. Gd-concentration data

\begin{tabular}{lccc}
\hline Compound & {$[\mathrm{Gd}]^{a}, \mu \mathrm{M}$} & {$[\mathrm{Gd}]^{b}, \mu \mathrm{M}$} & {$[\text { Protein }]^{\mathrm{c}}, \mathrm{mg} / \mathrm{mL}$} \\
\hline $\mathbf{1 3}$ (exterior) & 230.0 & 206.0 & 6.0 \\
$\mathbf{1 4}$ (interior) & 420.0 & 403.0 & 11.0 \\
$\mathbf{S 9}$ (exterior control) & 1.92 & $\mathrm{nd}$ & $5.0^{*}$ \\
$\mathbf{S 1 0}$ (interior control) & 2.69 & $\mathrm{nd}$ & $5.0^{*}$ \\
No protein & 1.17 & $\mathrm{nd}$ & $\mathrm{na}$ \\
\hline
\end{tabular}

${ }^{a}$ determined by ICP-AES

${ }^{b}$ determined by mineralization monitored by relaxometry

${ }^{c}$ subunit (monomer) concentration by SDS-PAGE and densitometry following capsid disassembly (determined within $1.0 \mathrm{mg} / \mathrm{mL}$ )

* initial concentration of protein incubated with $\mathrm{GdCl}_{3}$

\section{Relaxivity Determination}

The ${ }^{1} \mathrm{H}$ longitudinal water proton relaxation rates were measured at $20 \mathrm{MHz}$ on a Spinmaster spectrometer (Stelar, Mede, Italy) operating in the range $0.45-1.6 \mathrm{~T}$ (corresponding to 20-70 $\mathrm{MHz}$ proton Larmor frequencies). The standard inversion recovery method was used with typical $90^{\circ}$ pulse width of $3.5 \mu \mathrm{s}, 16$ experiments of 4 scans. The reproducibility of the $T_{1}$ data was $\pm 4 \%$. The temperature was controlled with a Stelar VTC-91 airflow heater equipped with a calibrated copperconstantan thermocouple (uncertainty of $\pm 0.1^{\circ} \mathrm{C}$ ).

The relaxivity, $r_{1 \mathrm{p}}\left(\mathrm{mM}^{-1} \mathrm{~s}^{-1} ; 25^{\circ} \mathrm{C}\right)$, was calculated from the observed relaxation rates, $\mathrm{R}_{1}{ }^{\text {obs }}$, by using the following expression:

$$
\left.r_{1 \mathrm{p}}=\left(\mathrm{R}_{1}{ }^{\text {obs }}-0.43\right) /[\mathrm{Gd}] \quad \text { (eq. } 2\right)
$$

where 0.43 is the the relaxation rate $\left(25^{\circ} \mathrm{C}\right)$ of an identical solution without the paramagnetic metal ions and [Gd] is given by eq. 1 . 


\section{References}

1 (a) Hooker, J.M., Kovacs, E.W., and Francis, M.B. (2004). Interior surface modification of bacteriophage MS2. J. Am. Chem. Soc. 126, 3718-3719. (b) Bagnato, J.D.E., A. L.; Horton, R. A.; Grissom, C. B. (2004). Synthesis and Characterization of a Cobalamin-Colchicine Conjugate as a Novel Tumor-Targeted Cytotoxin. J. Org. Chem. 69, 8987-8996. (c) Krumpe, L.R.H., and Mori, T. (2006). The use of phage-displayed peptide libraries to develop tumor-targeting drugs. International Journal of Peptide Research and Therapeutics 12, 79-91.

2 (a) Hancock, W. S.; Battersby, J. E. Anal. Biochem. 1976, 71, 260-264. (b) Smith, D. B.; Johnson, K. S. Gene, 1988, 67, 31-40. (c) Vazquez, M. Eugenio; Blanco, Juan B.; Imperiali, B. J. Am. Chem. Soc 20051300 - 1306.

3 Serwinski, Paul R.; Esat, Burak; Lahti, Paul M.; Liao, Yi; Walton, Richard; Lan, Jiang; J. Org. Chem. 20045247 5260

4 Crich, S. G.; Biancone, L.; Cantaluppi, V.; Esposito, D. D. G.; Russo, S.; Camussi, G.; Aime, S. Magnet Reson Med 2004, 51, 938-944. 